石油技術協会誌 第 56 巻 第 3 号（平成 3 年 5 月）

JOURNAL OF THE JAPANESE ASSOCIATION FOR PETROLEUM TECHNOLOGY

VOL. 56, NO. 3 (May, 1991)

傾斜井におけるストリングの軸力

中 村 常 太*

（平成 3 年 1 月 18 日受付, 3 年 3 月 14 日受理）

\title{
Axial Loads of Strings in Directional Wells
}

By

\section{Tsuneta NAKAMURA}

\begin{abstract}
The buoyed weight method, and the weight (in the air) and pressure method have been used to calculate the weight of a string in a well. These methods have also been used to determine an axial load at any point in a string. Though an axial load must be determined, for instance, to make a bi-axial correction of collapse resistance of a casing and to practice the tri-axial stress casing design method, conventional methods to know axial loads can not be applied to strings in directional wells.

A theoretical investigation of loads in strings in directional wells was performed. Then a simple method to determine axial loads of strings in directional wells was developed. The key parameters of this method are vertical lengths of pipes, weight (in the air)/foot of pipes and hydrostatic pressures on pipes. The axial loads at the surface calculated with this new method almost coincide with actual field data.

This paper presents the investigation of loads in strings in directional wells and describes the new method to determine axial loads of strings. This paper also describes an idea how to predict drags of strings in directional wells.
\end{abstract}

\section{1.はじめに}

ケーシングに引張り力が働くと, 引張り力が無いとき と比べて，その圧潰耐力は減少し内圧耐力は增加する。 一方圧縮力が勧くと, 逆にその圧潰耐力は増加し内庄耐 力は減少する。以上は広く知られるところであるが, ケー シング設計においては，引張り力が働いたときの圧潰耐 力の減少のみを考虑するのが一般的である。「ケーシン グの圧潰耐力」と「ケーシング圧潰耐力の 2 軸補正」に ついては「API bulletin 5C3」に規定されており，石 油資源開発㑣でもその規定に従って圧潰についてのヶー シング設計を行っている。ケーシング圧瀆耐力の補正手 順を図 1 に示す。この方法では，坑井内のケーシングの 軸力 (石油資源開発㑣では降下直後の状態を採用) を計

*石油凟源開発株式会社 作井部

Copyright (C) 1991, JAPT

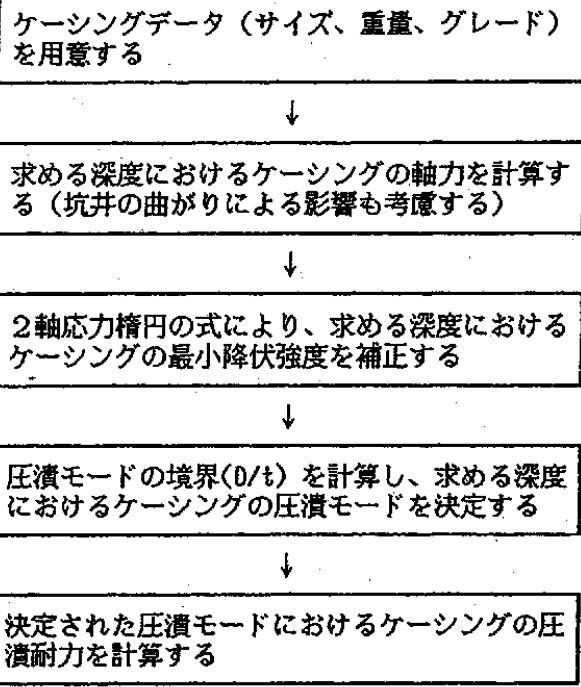

図 1 軸力を考虑したケーシング圧潰雨力の計算 手順 (API bulletin $5 \mathrm{C} 3$ ) 
算し，それと 2 軸応力棈円の式からそのパイプの最小降 伏強度を補正する。そして補正された最小降伏強度によ り，そのパイプの圧潰モードを決定し圧湞耐力を計算す る。

一方，3 軸応力法によりケーシング設計を行う場合に あ, 坑井内のケーシングの軸力を正しく知ることが不可 欠である。また，ドラグの無い状態でのストリング(ケー シングを含む) の軸力あるいは自重 (愻垂重量) の理論 的な值を知ることは，実際の吊荷重がどの程度のドラグ を含んでいるかを知る上で重要である。

このように坑井内ストリングの任意の深度における軸 力を知ることは，ヶーシングやドリルストリングの設計 において, また実作業上の様々な許容値・限界值等を知 る上で重要である。

垂直井内のストリングの軸力計算法（後述）は広く知 られている。しかし，その方法を䫅斜井内のストリング にそのまま適用することはできない。また，ドラグの無 い状態での㑯斜井内のストリングの吊荷重を, 重直井内 のそれのように, 空中重量 $\times$ 浮力係数で求めることは
できない。極端な例として，水平坑井内の水平区間のス トリングは, 坑壁の垂直抗力によって支えられているの であって地表加ら䊝垂されているのではない。従って水 平坑井内のストリングの自重 (愳垂重量) は, ドラグが 無いものとしてあ空中重量と浮力係数によってて求めら れない。

この論文は，新たに導かれた，ドラグの無い状態での 㑯斜井内のストリングの簡便な軸力計算法について述べ るものである。また，傾斜井内のストリングのドラグ計 算についても言及する。

\section{2. 頓斜井におけるストリングの自電の実際}

傾斜井におけるストリングの自重の実際をデイリード リリングレポート他から調查した。ケーシングの自重に ついては，降下後の管動時の吊荷重を分析しない限り は，その実際の值を知ることは難しい。そこで調查の対 象をドリルストリングの自重に絞り，ここ数年の間に掘 削された傾斜井における，ドリルストリングの「自重」 （オフボトムでストリングを回転させた時の吊荷重）と

表 1 頃斜井におけるドリルストリング自重の実際と計算値の比較

\begin{tabular}{|c|c|c|c|c|c|c|c|c|c|}
\hline 坑井名 & $\begin{array}{l}\text { 坑 径 } \\
(\text { インチ) }\end{array}$ & $\begin{array}{c}\text { 掘削深度 } \\
(\mathrm{m})\end{array}$ & $\begin{array}{l}\text { 埿水 } \\
\text { 比重 }\end{array}$ & $\begin{array}{l}\text { 坑底での } \\
\text { 碩斜角 }\end{array}$ & 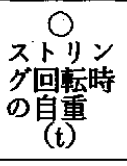 & 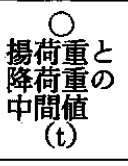 & 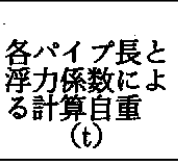 & 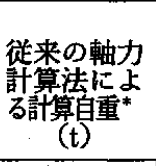 & 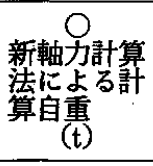 \\
\hline \multirow{2}{*}{ A } & $8-1 / 2$ & 2,094 & 1.68 & $46^{\circ} 00^{\prime}$ & 55 & 56.5 & 74.4 & 81.3 & 58.2 \\
\hline & $12-1 / 4$ & 1,314 & 1.58 & $46^{\circ} 45^{\prime}$ & 46 & 46.5 & 59.6 & 64.0 & 48.3 \\
\hline \multirow{2}{*}{ B } & $8-1 / 2$ & 3,566 & 1.33 & $48^{\circ} 30^{\prime}$ & 87 & 92.0 & 116.3 & 120.4 & 91.7 \\
\hline & $12-1 / 4$ & 2,537 & 1.18 & $43^{\circ} 00^{\prime}$ & 76 & 78.0 & 97.4 & 102.8 & 78.6 \\
\hline \multirow{2}{*}{$\mathrm{C}$} & $8-1 / 2$ & 3,561 & 1.45 & $35^{\circ} 00^{\prime}$ & 96 & 109.0 & 111.4 & 117.7 & 101.4 \\
\hline & $12-1 / 4$ & 2,864 & 1.60 & $30^{\circ} 15^{\prime}$ & 87 & 93.0 & 99.2 & 105.0 & 91.2 \\
\hline \multirow{2}{*}{ D } & $8-1 / 2$ & 3,003 & 1.76 & $26^{\circ} 00^{\prime}$ & 90 & 92.0 & 98.2 & 103.0 & 97.9 \\
\hline & $12-1 / 4$ & 2,007 & 1.30 & $3^{\circ} 30^{\prime}$ & 84 & - & 84.6 & 86.5 & 86.3 \\
\hline \multirow{2}{*}{$\mathrm{E}$} & $8-1 / 2$ & 2,345 & 1.24 & $14^{\circ} 00^{\prime}$ & 75 & 78.5 & 84.4 & 87.1 & 82.6 \\
\hline & $12-1 / 4$ & 1,307 & 1.16 & $22^{\circ} 00^{\prime}$ & 56 & 54.0 & 60.5 & 62.4 & 57.2 \\
\hline \multirow{2}{*}{$\mathbf{F}$} & $8-1 / 2$ & 2,305 . & 1.47 & $22^{\circ} 00^{\prime}$ & 63 & 64.5 & 79.4 & 84.1 & 70.3 \\
\hline & $12-1 / 4$ & 2,135 & 1.22 & $26^{\circ} 10^{\prime}$ & 62 & 68.0 & 80.3 & 84.2 & 69.7 \\
\hline \multirow{2}{*}{$\mathrm{G}$} & $8-1 / 2$ & 2,205 & 1.23 & $53^{\circ} 30^{\prime}$ & 55 & 57.5 & 80.6 & 86.1 & 61.0 \\
\hline & $12-1 / 4$ & 1,553 & 1.16 & $52^{\circ} 00^{\prime}$ & 48 & 49.0 & 66.3 & 70.0 & 52.8 \\
\hline $\mathrm{H}$ & $8-1 / 2$ & 4,805 & 1.63 & $17^{\circ} 15^{\prime}$ & 130 & 137.0 & 144.3 & 150.6 & 147.5 \\
\hline
\end{tabular}

○管径変化点のショルダーエリア及びボトムエリア には, 以下の数値を使用した。(単位 $\mathrm{cm}^{2}$ )

\begin{tabular}{c|c|c|c}
\hline$\times$ & $5^{\prime \prime}$ HWDP & $5^{\prime \prime}$ DP & ボトム \\
\hline $8^{\prime \prime}$ DC & 203.14 & - & 284.21 \\
\hline $6-12^{\prime \prime}$ DC & 101.34 & - & 182.41 \\
\hline $5^{\prime \prime}$ HWDP & - & 47.04 & - \\
\hline
\end{tabular}

* 垂直井における軸力計算法をそのまま傾斜井に適用し た場合の計算自重

（管径変化点及び坑底に作用する泥柱圧を垂直深度 で計算するのみを変更）

(0) 8-1/2" 坑の坑内編成 :

8-1/2" ビット $\times 6-1 / 2^{\prime \prime} \mathrm{DC} \times 5^{\prime \prime} \mathrm{HWDP} \times 5^{\prime \prime} \mathrm{DP}$ (012-1/4" 坑の坑内編成 :

$12-1 / 4^{\prime \prime}$ ビット $\times 8^{\prime \prime} \cdot \mathrm{DC} \times 5^{\prime \prime} \mathrm{HWDP} \times 5^{\prime \prime} \mathrm{DP}$ 
ドリルストリングの揚荷重・降荷重の中間値を調查した。 吊具重量は差し引き，正味のドリルストリング重量を求 めた。

以上により調査した自重と，各パイプ長と浮力係数に よる計算自重, 従来の軸力計算法による計算自重（坑底 および管径変化点に作用する泥柱圧を垂直深度で計算す る以外は，垂直井における方法と同じ)，およびこれか ら解説する新軸力計算法による計算自重を坑井毎にまと めたのが表 1 である。自重の実測值（ストリング回転時 の自重之, 揚荷重・降荷重の中間值）は, 多少のドラグ を含んでいる可能性はあるものの,「真の自重」(ドラグ の無い状態での地表の愁垂重量）に近い値と考えられ る。一方, 各パイプ長と浮力係数による計算自重は, い ずれの坑井においてあ自重の実測値よりかなり大きく， 時に揚荷重よりあ大きくなり，「真の自重」を表してい るとは到底考えられない。従来の軸力計算法による計算 自重についても同様である。このことは, 浫力伱数によ る自重計算法, あるいは従来の軸力計算法が傾斜井には 適用できないことを示唆する。液体で満たされたコップ の中に吊り下げられたパイプの重量は, その形状にかか わらず空中重量 $\times$ 浮力係数で求められる。しかし傾斜井 内のストリングの重量は, たとえドラグの無い状態であっ ても坑壁のどこかでその一部が支えられているので, 空 中重量と浮力係数のみでその自重を算出することはでき ない。前述のように，水平坑井では水平区間のストりン グでは坑壁の垂直抗力によって支えられており，地表か らは㯺垂されていない。

一方, これから解説する新軸力計算法による計算自重 は, 各坑井とも, 自重の実测值と非常に近い值である (表 1 中○印参照)。この新しい手法は, 現実と矛盾して いないと言える。ただし深い坑井では, ツールジョイン トの影讋による若干の誤差が生じる。これは, 垂直井に 対し従来の㓓力計算法を適用した場合にあ現れる誤差で あり,パイプの単位長さ当たりの空中重量を補正すれば 解消できるあのと考えられる。

\section{3. パイプに䇙く浮力}

\section{1 鉛直なパイプに都く浮力}

ショルダーの無い鉛直なパイプに嘢く浮力の考え方を 図 2 に示す。液面はパイプの上端にある。水平方向の力 は泥柱圧による力ですべて相殺されるので，鉛直方向に 作用する力のみを次のように考える。

吊荷重 (泥水中重量)

$$
\text { =パイプの空中重量一パイプの底面にかかる力 }
$$

パイプの底面にかかる力

$=$ 坑底圧力(パイプの底面にかかる圧力) $\times$ 底面積

$=[0.1 \rho \times L] \times\left[\pi / 4\left(O D^{2}-I D^{2}\right)\right] \quad(\mathrm{kgf})^{\text {i主 } 1)}$

$=\left[\pi / 4\left(O D^{2}-I D^{2}\right) \times 100 L\right] \times \rho \times 0.001 \quad(\mathrm{kgf})$

=パイプの体積 $\times$ 泥水密度

パイプにショルダーがある場合には，そこに作用する上 または下向きの力（泥柱圧による力）を考え合わせれば 良い。浮力はパイプの底面（およびショルダー面）に作 用する泥柱圧による力と考えても，アルキメデスの原理 と何ら矛盾しない。

\section{2 傾斜したパイプに颉く浮力}

ショルダーの無い傾斜したパイプに䁫く浮力の考え方 を図 3 に示す。液面はパイプの上端にある。パイプの底 面と側面にかかる力の鉛直方向の成分の合力を浮力と考 える。

・パイプの底面にかかる力＝坑底圧力 $\times$ 底面積

$$
=[0.1 \rho \times L \cos \theta] \times\left[\pi / 4\left(O D^{2}-I D^{2}\right)\right]
$$

(1)の鉛直上向き成分 $=$ (1) $\times \cos \theta$

$$
=\underline{0.1 \rho \times \pi / 4 L \cos ^{2} \theta \times\left(O D^{2}-I D^{2}\right)} \cdots \cdots \text {...(2) }
$$

・パイプの外面にかかる力(パイプの中心軸に垂直・上 向き）

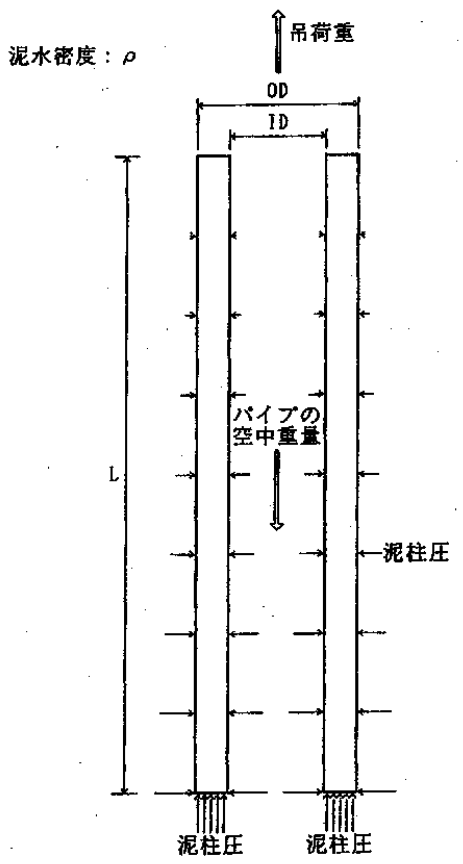

図 2 鉛直なパイプに働く浮力

注 1) 図 2,3 において, 各記号の単位を $\rho\left(\mathrm{g} / \mathrm{cm}^{3}\right), L(\mathrm{~m})$, $O D(\mathrm{~cm}), I D(\mathrm{~cm})$ とすると, 本章に抬ける力の単位は kgf となる。 


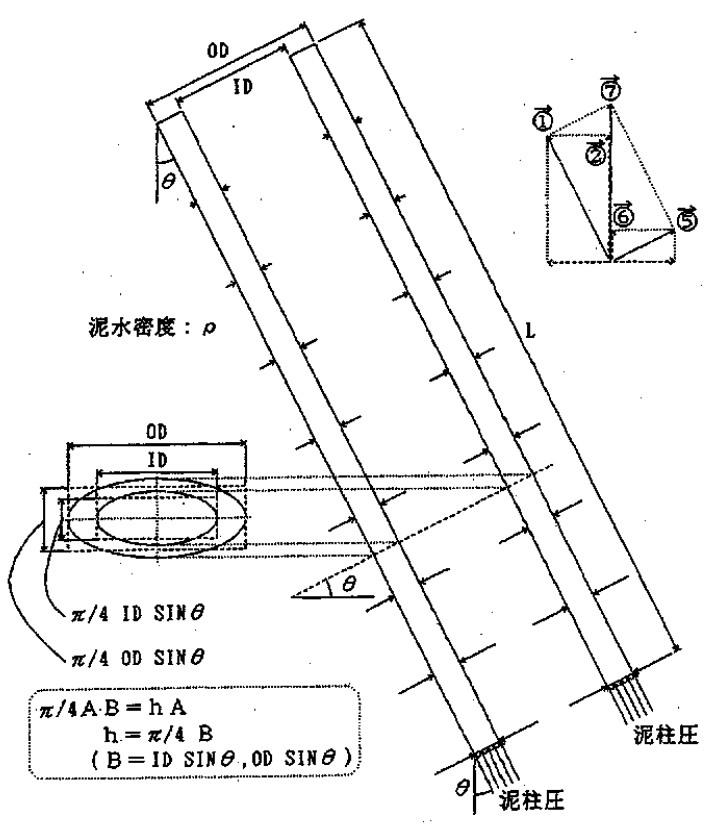

図 3 頃斜したパイプに働く浮力

（中心軸に垂直な切断面の鈶直面への投影において， パイプ外周の棈円と等面積の長方形を考える)

=微小圧力差 $\times$ その圧力が作用する面積

$=[0.1 \rho \times \pi / 4 O D \sin \theta] \times[O D \times L] \cdots \cdots$ (3)

・パイプの内面にかかる力（パイプの中心軸に垂直・下 向き)

=微小圧力差 $\times$ そ圧力が作用する面積

$=[0.1 \rho \times \pi / 4 I D \sin \theta] \times[I D \times L]$

・パイプの内・外面にかかる力の合力(パイプの中心朝 に垂直・上向き）

$$
\begin{aligned}
& =(3)-(4) \\
& =0.1 \rho \times \pi / 4 L \sin \theta \times\left(O D^{2}-I D^{2}\right)
\end{aligned}
$$

(5)の鉊直上向き成分 $=$ (5) $\times \sin \theta$

$$
\begin{aligned}
& =0.1 \rho \times \pi / 4 L \sin ^{2} \theta \times\left(O D^{2}-L D^{2}\right) \\
& \text { ・ パイプ全体の浮力=(2)+(6) } \\
& =0.1 \rho \times \pi / 4 L\left(O D^{2}-I D^{2}\right) \\
& \times\left(\cos ^{2} \theta+\sin ^{2} \theta\right) \\
& =\underline{0.1 \rho \times L \times \pi / 4\left(O D^{2}-I D^{2}\right)}
\end{aligned}
$$

鉛直なパイプと比べて, 底面にかかる力は泥柱圧減少 分小さくなり，その鉛直上向き成分は傾斜角に従いさら に小さくなる。しかし，パイプ内・外面の受ける力の合 力の銛直上向き成分がそれを補填し，結局鉛直上向き成 分の合力は，鈶直なパィプの底面にかかる力と等しくな

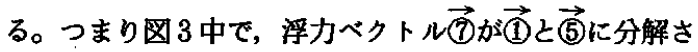
れる。

\section{3 坑井内のストリングに鹪く浮力}

このようにパイプに雔く浮力は，泥柱圧による力の鈶 直方向成分の合力であり，パイプの傾斜角にかかわらず 一定である。ドラグの無い状態での傾斜井内のストリン グの自重 (篻垂重量) が, 空中重量に浮力係数を掛けた 值すなわち空中重量功浮力を差し引いた值より小さい のは, 坑壁の垂直抗力がストリング重量の一部を保持し ているに他ならない。

\section{4. 坑井内のストリングの軸カ}

\section{1 垂直井におけるストリングの軸力}

垂直井におけるストリングの軸力図（深度対軸力）の 例を図 4 に示す。左方が圧縮，右方が引張りである。ス トリングに㗢く水平方向の力は，泥柱圧による力です心゙ て相殺されている。そして鉿直方向には, パイプの空中 重量と浮力が倠く。全深度にわたりパイプの断面積が 均一であれば, 前述のとおり浮力は坑底圧力 $\times$ 底面積な る上向きの力として底面のみに僛く。底面はこの浮力に よる圧縮を受けている。そして樑度が小さくなるにつれ て, パイプの空中重量勾配 (単位長さ当たりの空中重量) に従いこの圧縮力は低下し，ある㳭度で引張りに転じ， 地表では自重（牀垂重量・吊荷重）となる。管径変化点 があれば，それらに応じたショルダーフォースが碀く。 こうして求めた自重は, 空中重量に浮力係数を掛けた值 (泥水中重量) と理論的に等しい（前述）。任意の深度に おけるストリングの軸力を求める場合には，このような 軸力図を考えるのが一般的である。

以上の考え方は世界的に広く認められており，石油資 源開発㑣でもケーシング設計における区潰耐力の 2 朝補 正時等の軸力計算法として採用されてきた。㑯斜井につ いては, パイプの底面とショルダー面に影く泥柱在のみ を変更（垂直深度による值を使用）してこの方法を適用 していた。しかし，同じストリングを垂直井に降下した 場合と傾斜井に降下した場合とで自重の計算值が異なり, また垂直井においてのみその計算值が空中重量と浮力係 数による泥水中重量と等しくなるので, 傾斜井における 自重の計算值を検証するためにこのスタディーを始めた。 そして, 㑯斜井内のストリングについては, 泥柱圧を変 更するのみではこの方法を適用できないことが判明し， 傾斜井における新たな軸力計算法が導かれた。次節でそ れを解説する。

\section{2 梖斜井におけるストリングの軸力}

\subsection{1 傾斜井内のストリングに穐く力}

傾斜井内のストリングに働く力は, パイプの空中重量, 泥柱圧による力, 坑壁の抗力, 地表での懸垂力（吊荷 重), およびドラグである。それらの例（垂直 $\rightarrow$ 増角 $\rightarrow$ 

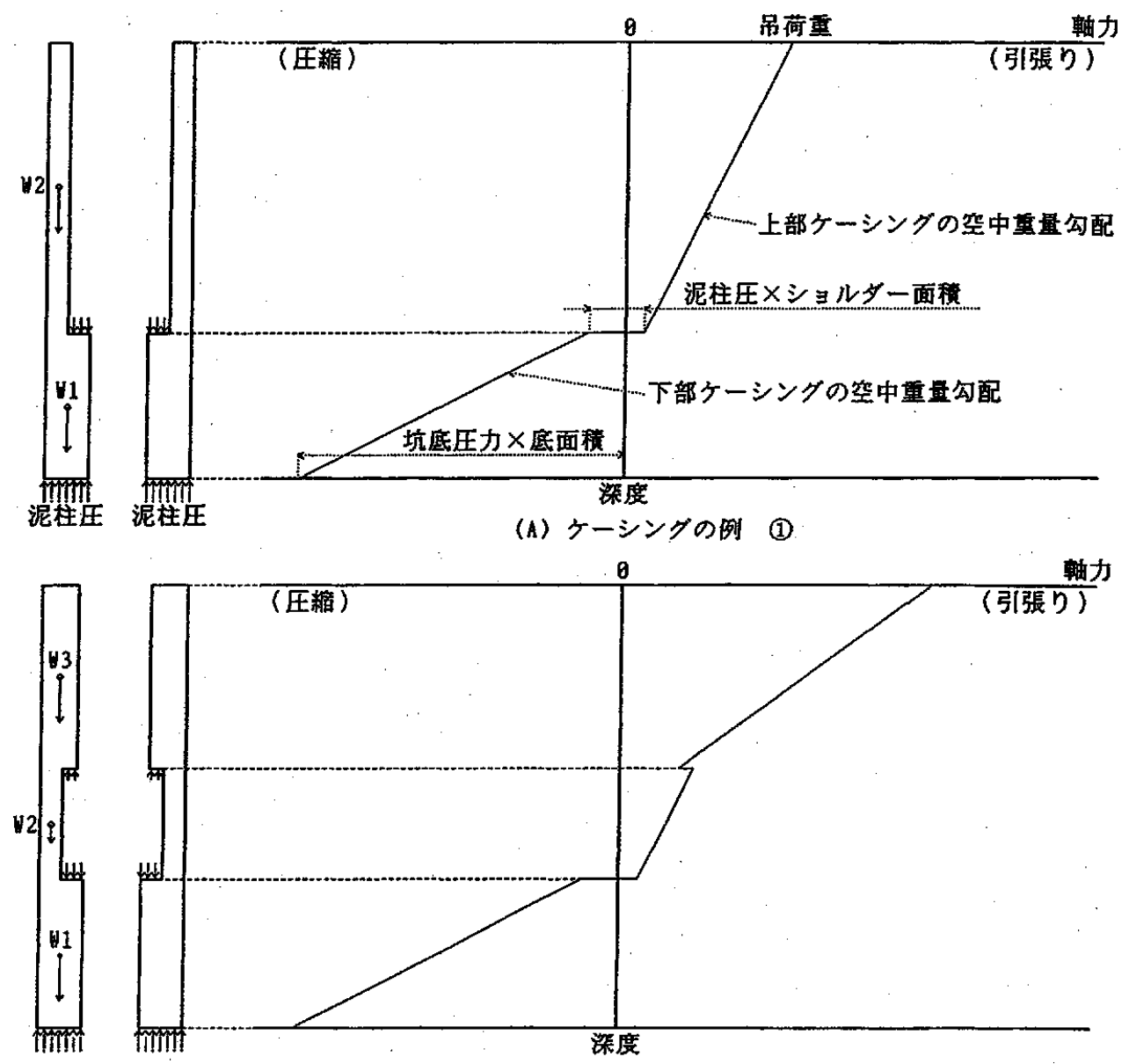

(B) ケーシングの例 (2)

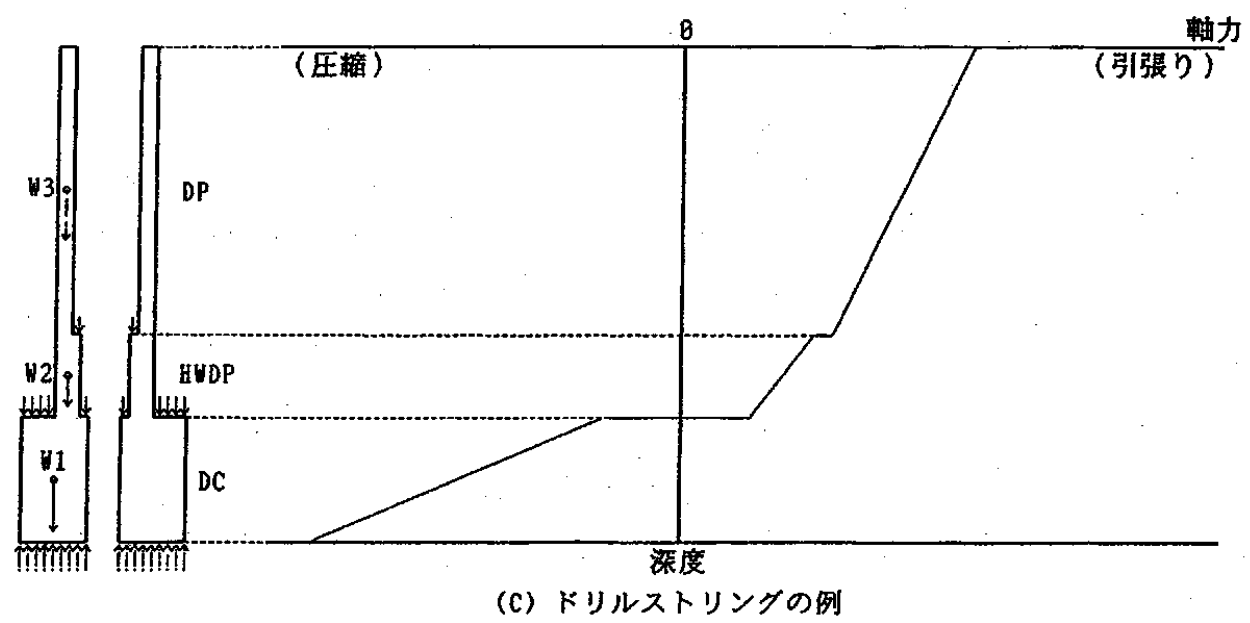

図 4 垂直井におけるストリングの軸力図 


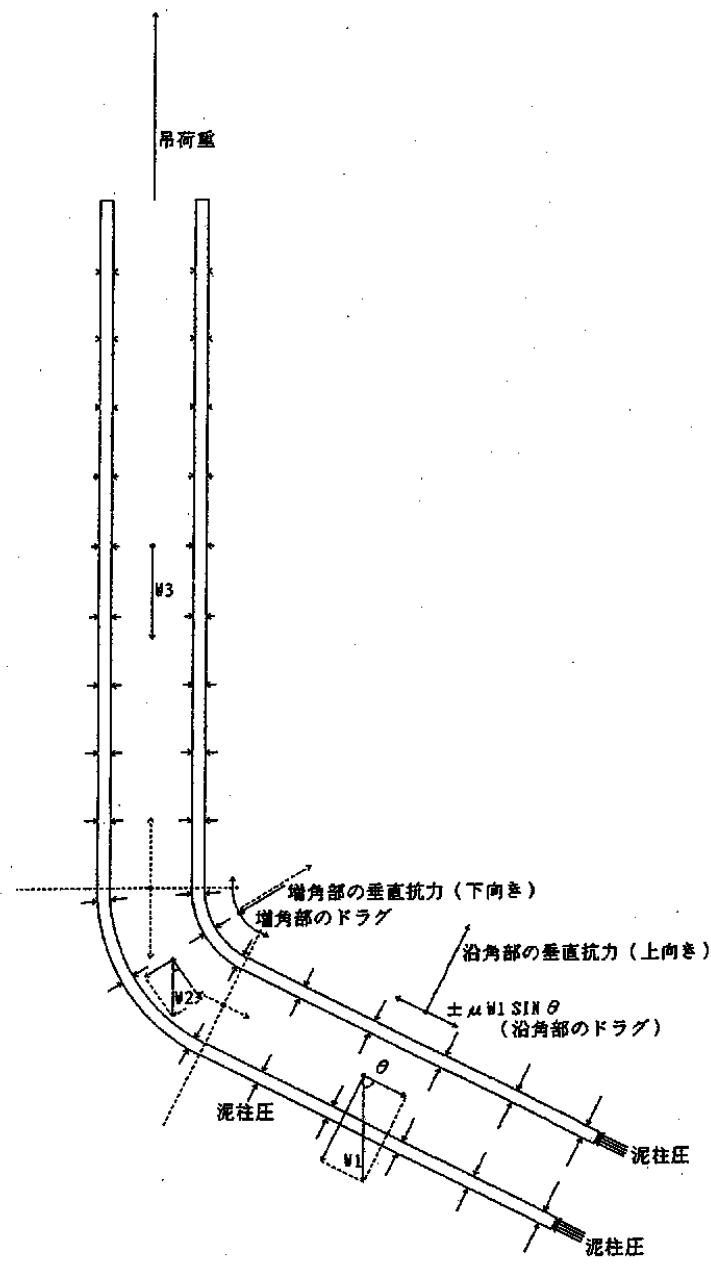

図 5 頃斜井内のストリングに動く力

浻角）を図 5 に示す。ここではパイプの岡性による力は 無視している。堌 (減) 角部では, その区間両端に鹳く 張力の分力の反力としての抗力が坑塈に働く。これは, 滑車に括いてそれを支える腕の力と理解すれば良い。以 下に図 5 のストリングを例として, 傾斜井内のストリン グに䣸く力を区間毎に区切って考える。

\subsection{2 垂直区間のパイプに倠く力} 水平方向には，泥柱圧による力のみが作用し，それら はすべて相殺されている。鉛直方向には，下の区間加ら の張力, この区間のパイプの空中重量，おょび地表での 張力 (吊荷重) が儌く。軸力図で考えれば，これら二つ の張力をパイプの空中重量勾配の直線で結ぶことになる。 この区間に浮力は働かない。また理想的な状態において は，垂直区間のドラグは 0 である

\section{2 .3 沿角区間のパイプに働くカ} 沿角区間内の微小区間のパイプに働く力を図 6 に示す。
パイプの中心軸方向（朝力方向）には，微小区間両端の 張力, 空中重量の $\cos \theta$ 成分, およびドラグが锄く。中 心軸に垂直な方向には, 空中重量の $\sin \theta$ 成分, 微小区 間の側面からの浮力, および坑壁の垂直抗力が働く。

・沿角微小区間の軸力変化(增)分

$$
\Delta T=W \Delta L \cos \theta \pm \mu(W \Delta L \sin \theta-\Delta F b)
$$

ドラグを 0 とすれば

$$
\begin{aligned}
\Delta T & =W \Delta L \cos \theta \\
& =W \times(\Delta L \cos \theta)
\end{aligned}
$$

・ドラグが 0 の場合の沿角全区間の軸力変化(増)分

$\Sigma \Delta T=W(\Sigma \Delta L) \cos \theta$ $=\underline{W \times L h \cdot \cos \theta}$

・沿角微小区間のドラグ

$$
\begin{aligned}
& = \pm \mu(W \Delta L \sin \theta-\Delta F b) \\
& = \pm \mu\left(W^{\prime} \Delta L \sin \theta\right)
\end{aligned}
$$

・沿角全区間のドラグ

$$
\begin{aligned}
& = \pm \mu\left[W^{\prime}(\Sigma \Delta L) \sin \theta\right] \\
& = \pm \mu\left(W^{\prime} L h \cdot \sin \theta\right)
\end{aligned}
$$

ドラグの無い状態における沿角微小区間の軸力変化分は, 単位長さ当たりのパイブ空中重量 $\times$ 沿角微小区間の垂直 距離となる。よって沿角全区間の軸力変化分は, 単位長 さ当たりのパイプ空中重量 $\times$ 浻角区間の垂直距離となる。 軸力図では, 沿角区間両端の垂直深度をパイプの空中重 量勾配で結ぶことになる（ショルダーが有ればそれを考 慮する)。

垂直抗力中の $\triangle F b$ は, 図 3 に括けるべクトル(5)，つ まりアルキメデスの原理での「浮力」の $\sin \theta$ 成分と等 しいので, 空中重量の $\sin \theta$ 成分と $\Delta F b$ の合力は, こ の微小区間の泥水中重量（空中重量 $\times$ 浮力係数）の $\sin$ $\theta$ 成分と等しい。従って沿角全区間のドラグは, 沿角区 間のパイプの泥水中重量の $\sin \theta$ 成分に摩擦係数を散け たものとなる。

\subsection{4 增（減）角区間のパイプに政く力}

増角区間内の微小区間のパイプに倠く力を図 7 に示す。 沿角区間との違いは，微小区間両端の張力が一直線上に 乗らないので, それらの $\sin (\Delta \theta / 2)$ 成分の反力として の垂直抗力が付加されることである。つまり坑壁の垂直 抗力は, これらの垂直抗力之, 空中重量の $\sin \bar{\theta}$ 成分之 微小区間の側面功の浮力の反力としての垂直抗力との 合力になる。

-増角微小区間の軸力変化(増)分

$$
\Delta T=W \Delta L \cos \bar{\theta} \pm \mu F n
$$

ドラグを 0 とすれば

$$
\begin{aligned}
\Delta T & =W \Delta L \cos \bar{\theta} \\
& =W \times(\Delta L \cos \bar{\theta})
\end{aligned}
$$

・ドラグが 0 の場合の増角全区間の軸力変化(増)分 


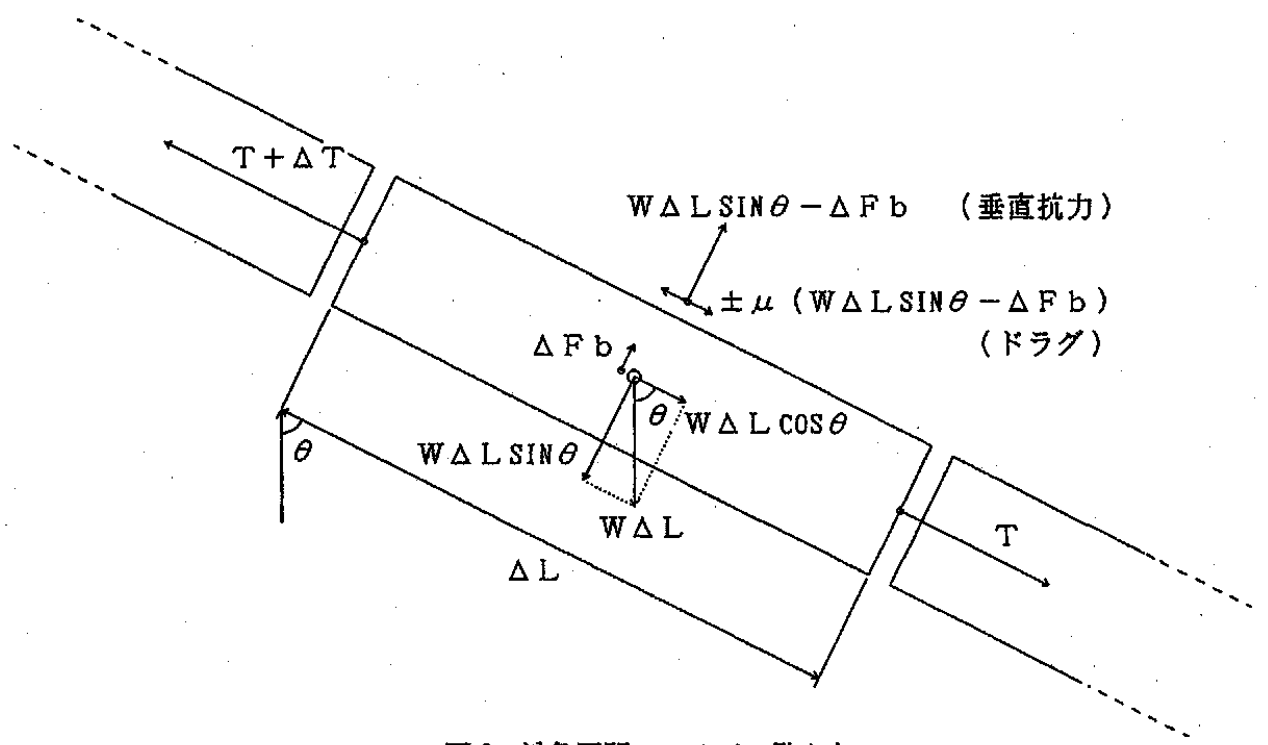

図 6 沿角区間のパイプに動くカ

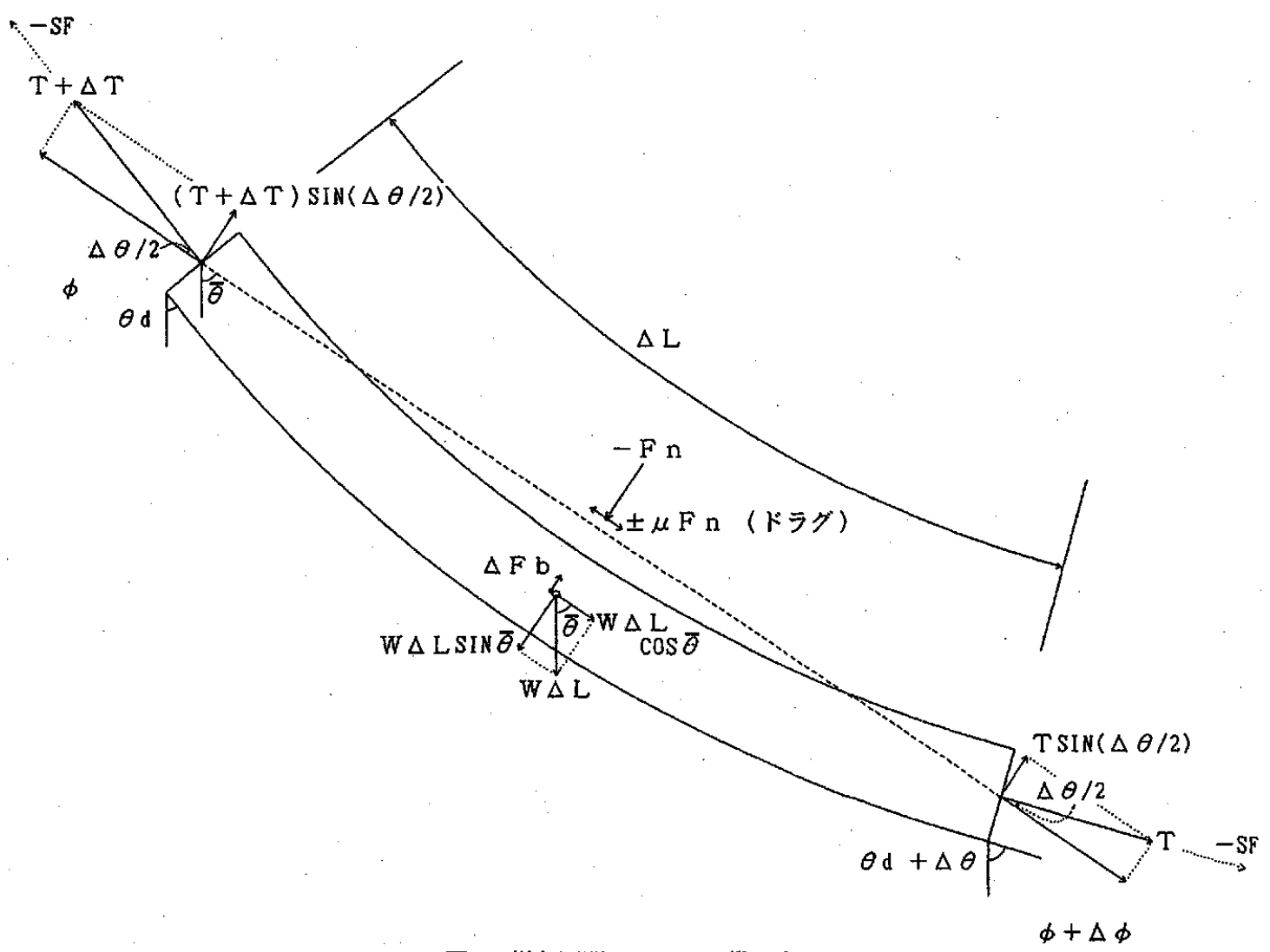

図 7 増角区間のパイプに㒖くカ 
$\Sigma \Delta T=\underline{W \times \Sigma(\Delta L \cos \bar{\theta})}$

・増角微小区間のドラグ

$$
\begin{aligned}
\pm \mu F_{n}= & \pm \mu[W \Delta L \sin \bar{\theta}-\Delta F b \\
& -\left(T^{\prime}+\Delta T^{\prime}\right) \sin (\Delta \theta / 2) \\
& \left.-T^{\prime} \sin (\Delta \theta / 2)\right] \\
& \fallingdotseq \pm \mu\left[W^{\prime} \Delta L \sin \bar{\theta}\right. \\
& \left.-\left(T^{\prime}+\Delta T^{\prime}\right) \Delta \theta / 2-T^{\prime} \Delta \theta / 2\right] \\
= & \pm \mu\left(W^{\prime} \Delta L \sin \bar{\theta}-T^{\prime} \Delta \theta\right. \\
& \left.-\Delta T^{\prime} \Delta \theta / 2\right) \\
& \fallingdotseq \pm \mu\left(W^{\prime} \Delta L \sin \bar{\theta}-T^{\prime} \Delta \theta\right)
\end{aligned}
$$

・增角全区間のドラグ

$$
= \pm \mu \Sigma\left(W^{\prime} \Delta L \sin \bar{\theta}-T^{\prime} \Delta \theta\right)
$$

・この微小区間について，方位角変化も考慮した場合の 坑壁の垂直抗力を考えると水平方向について上記と同 様に考えて

$$
\begin{aligned}
F n h & =\left[T h^{\prime} \sin (\Delta \phi / 2)\right] \times 2 \\
& =T h^{\prime} \Delta \phi \\
& =\left(T^{\prime} \sin \bar{\theta}\right) \Delta \phi \\
N & =\sqrt{F n^{2}+F n h^{2}} \\
& =\sqrt{\left(W^{\prime} \Delta L \sin \bar{\theta}-T^{\prime} \Delta \theta\right)^{2}+\left(T^{\prime} \Delta \phi \sin \bar{\theta}\right)^{2}}
\end{aligned}
$$

よって方位角変化す考慮した場合の増角微小区間のドラ グは

$$
\begin{aligned}
& \pm \mu N \\
& = \pm \mu \sqrt{\left(W^{\prime} \Delta L \sin \bar{\theta}-T^{\prime} \Delta \theta\right)^{2}+\left(T^{\prime} \Delta \phi \sin \bar{\theta}\right)^{2}}
\end{aligned}
$$

ドラグの無い状態における増角微小区間の朝力変化分 は，沿角微小区間同様，単位長さ当たりのパイプ空中重 量×微小区間の垂直距離となる。よって増角全区間の軸 力変化分は, 単位長さ当たりのパイプ空中重量 $\times$ 増角 区間の垂直距離となる。軸力図では，増角区間両端の 垂直樑度をパイプの空中重量勾配で結ぶことになる(ショ ルダーが有ればそれを考慮する)。

微小区間の空中重量の $\sin \bar{\theta}$ 成分之側面加らの浮力の 合力は, 沿角微小区間同様この微小区間の泥水中重量の $\sin \bar{\theta}$ 成分と等しW $\left(W \Delta L \sin \bar{\theta}-\Delta F b=W^{\prime} \Delta L \sin \bar{\theta}\right)$ 。

一般に, 真の軸力とスタビリティーフォース注2)の差

注 2) スタビリティーフォース $(S F)$

$$
=A i P i-A o P o
$$

(引張りが正)

パイプの内・外圧が等しい場合,

$S F=(A i-A O) P$

=ーパイプの断面栍 $\times$ 泥柱压

この時, スタビリティーフォースは泥柱圧による圧 綰力になる。しかし周囲圧力による圧縮力なので，軸 力がそれを上回る圧縮力にならない限りストリングが バックリングすることはない。

バックリングに作用する力は, 真の軸力からスタビ

リティーフォースを差し引いた力で, バックリングフォ ースと乎ばれる。
に相当する力（バックリングフォース）が，ストリング のバックリングに寄与すると言われる。図７において, 坑底近くの微小区間に扔ける真の軸力 $(T)$ は，た之え ストリングがオフボトムの状態（坑底加ら離れた状態） であってす，ストリングの底面に働く泥柱圧により非常 に大きな圧緶力となる（図 4 , 図 8 参照)。しかし坑底 近くの增角区間で，曲がったストリングがこの大きな圧 縮力の分力によって下方に強く押し付けられる（一種の バックリングを起こす）ことはない。バックリングフォー スが0（オフボトム状態のストリング最下部）であれ ば,パイプと垂直方向に坑壁に作用する力は，この微小 区間の泥水中重量の $\sin \bar{\theta}$ 成分のみになると考えられる。 従って増角区間において、ドラグを計算するために Fn を議論する場合， $T$ は $T^{\prime}$ (バックリングフォース)に置 き換えるのが妥当であろう。この場合，各深度における スタビリティーフォースはそれぞれの微小区間における 図 3 でのベクトル(1)と等しいので, ドラグが無いときの $\Delta T^{\prime}$ は，微小区間の空中重量の $\cos \bar{\theta}$ 成分とアルキメ デスの原理での「浮力」の $\cos \bar{\theta}$ 成分の差，すなわちそ の微小区間の泥水中重量の $\cos \bar{\theta}$ 成分となる。従ってあ る樑度における（ドラグを含んだ） $T^{\prime}$ は，それ以深の 微小区間における泥水中重量の $\cos \bar{\theta}$ 成分の累計とドラ グの累計の和となる。ある微小区間のドラグは，そこで の $T^{\prime}$ 他により計算される。要するに，増角区間におい てドラグを計算するために垂直抗力を論ずる場合には， 沿角区間と同様に泥水中重量ですべてを考えれば良い。

減角区間についても增角区間と全く同様である。微 小区間の軸力変化分は, その区間のパイプ空中重量の $\cos \bar{\theta}$ 成分とドラグの和となる。ドラグの無い状態にお いては,これは単位長さ当たりのパィプ空中重量 $\times$ 微小 区間の垂直距離となり，隇角全区間の軸力変化は，単位 長さ当たりのパイプ空中重量 $\times$ 減角区間の垂直距離とな る。垂直抗力については， $\Delta \theta$ が負の值となるのみが異 なる。

\subsection{5 軸力計算方法のまとめ}

以上の各区間毎に，ドラグが無いときの軸力変化分と ドラグをまとめたのが表 2 である。ここで注意すべきこ とは，ドラグを考えない場合の（深度による）朝力変化 は，すべての区間に扔いて，単位長さ当たりのパイプ空 中重量とその区間の垂直距離で考えれば良いということ である。表中の下線部はそれぞれの区間の垂直長さであ る。軸力にドラグを考虑する必要の無い場合，左欄の計 算式に従い，垂直深度対軸力の図を描く。要は垂直，增・ 減・沿角にかかわらず，パイプの空中重量勾配で管径変 化点の垂直深度間を結ぶ。この方法により，直線のみて 非常に簡便な軸力図を描くことができる。 
表 2 頃斜井内のストリングに動く朝力

（方位角变化は考虑していない）

\begin{tabular}{|c|c|c|}
\hline 区間または場所 & ドラグが無いときの軸力変化分 & グ \\
\hline 垂 直 区 間 & $W \times \underline{L v}$ & $0(+\alpha)$ \\
\hline 増 - 減角区間 & $W \times \underline{\Sigma(\Delta L \cos \bar{\theta})}$ & $\pm \mu \Sigma\left(W^{\prime} \Delta L \sin \bar{\theta}-T^{\prime} \Delta \theta\right) \quad(+\alpha)$ \\
\hline 沿 角 区 間 & $W \times \underline{L h \cdot \cos \theta}$ & $\pm \mu\left(W^{\prime} L h \cdot \sin \theta\right) \quad(+\alpha)$ \\
\hline ストリングの底面 & 一坑底圧力 $\times$ 底面積 & $\longrightarrow$ \\
\hline 管径 变化点 & 土泥柱圧×ショルダー面積 & - \\
\hline 計 & $\begin{array}{l}\text {-坑底圧力 } \times \text { 底面積 }+W \times \text { 垂直長さ } \\
( \pm \text { (泥柱圧 } \times シ ョ ル タ ー \text { 面皘 } \quad(*)\end{array}$ & $\begin{array}{c} \pm \mu\left[\Sigma\left(W^{\prime} \Delta L \sin \bar{\theta}-T^{\prime} \Delta \theta\right)\right. \\
\left.+W^{\prime} L h \cdot \sin \theta\right] \quad(+a)\end{array}$ \\
\hline
\end{tabular}

下線部 : 各区間の垂直長さ

（*）：ドラグが無い状態での自重

管径が均一の場合 $\quad: W \times$ 垂直深度一坑底圧力 $\times$ 底面積

管径变化点がある場合 : 同一管径毎の $(W \times$ 管径変化点間の垂直長さ)の合計一坑底圧力 $\times$ 底面積士管

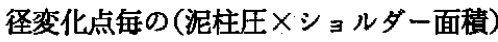

ドラグを考虑する場合には, 上記で求的た軸力に右欄 の力 (ドラグ) を付加する。增・減角区間については, 微小区間毎にドラグを累積しなければならない。ここで 言うドラグとは，理想的な状態での滑り摩擦である。実 際の坑井においては, 砟の滞留・落ち込み, 坑壁の迫り 出し，棚他による様々な揚降負荷を生ずる可能性がある ので, 表中では, これらをその他のドラグ $(\alpha)$ として 各区間に付加した。

\subsection{6 傾斜井における軸力計算例}

以上の計算法によりドラグが無い場合のドリルスト リングの軸力を計算した例（軸力図）が図8である。こ の坑井の据削梁度における㑯斜は， $46^{\circ} 00^{\prime}$ である。こ の方法による計算自重は, ストリング回転時の自重, お よび揚荷重と降荷重の中間値（いずれす実測値）に非常 に近い。浮力係数による計算自重, および従来の軸力計 算法による計算自重は, 揚荷重よりあ大きく，「真の自 重」を示しているとは到底考えられない。これらの計算 を複数の坑井に対して行ったのが表 1 であるが, 同様の ことが他の乱井についても言える。

\section{5. ストリングの軸力計算の適用}

\section{1 軸力計算の手法}

表 2 に従い，ドラグが無いときのストリングの軸力, およびドラグを計算する。前者は前述のように容易に手 計算で求められるが, 後者のうち「増・减角区間」につ いては，その中の微小区間に作用する力の積算が必要な ため、コンピュータプログラムを利用するのがその現実 的な計算手法となろう。いわゆる「トルク・ドラグ予测． プログラム」もいくつ加開発され, 市販されている。特
に水平掘の発展に伴い, 近年その開発は目覚ましい。そ れらがどの程度の機能を有しているかは不明であるが, ドラグを考虑した軸力を求めるために，いずれこういっ たプログラムは不可欠であり, その仕様検討が必要とな ろう。

以下に，ストリングの軸力計算の具体的適用について 述べる。

\section{2 ドラグを考慮しない場合の軸力計算の適用}

ドラグを考慮しない場合, 単位長さ当たりのパイブ空 中重量, 管径变化点の垂直深度, 底面とショルター面の 面積, およびそれらに働く泥柱圧により，任意の深度にお けるストリングの軸力を, 手計算で容易に求めることが できる。この場合の軸力計算は, 以下の目的で行われる。

5.2.1 ケーシング設計に扔ける圧潰耐力の 2 軸補正 (計算例 : 図 9)

「1.はじめに」で述べたように，引張り力が偟いたと きのケーシングの圧漬耐力の低下をその設計に組み込む 際に，坑井内のケーシングの軸力を知る必要がある。石 油資源開発俶では，ケーシング降下直後の状況を想定し てこの 2 朝補正を行うので, ケーシング降下時の泥水比 重を用いて表 2 の計算を行い，軸力図（垂直深度対軸力） を描いている。さらに「増・減角区間」については, 「曲げ」による引張り荷重 (bending load) を考感し ている。この計算例が図 9 である。これは，図 1 におい て2段目の作業である。

\section{2 .23 軸応力法によるケーシング設計}

3 軸応力法によりケーシング設計を行う場合には, 任 意の深度におけるパイプの軸方向応力, 半径方向応力そ して円周方向応力を知る必要がある。その軸方向応力は， 
坑井内のケーシングの軸力から計算される。

\section{2 .3 ストリングのドラグの実測}

坑井内のあらゆるストリングについて，ドラグが無い 状態での自重の理論值をあらかじめ知っておけば，その ストリングの実際の吊荷重から実際のドラグの值を知る
ことができる。これにより，例えば坑内状況を予測する ことができる。

5.2.4 最大ビット荷重の計算(計算例 : 図10, 図11) 軸力図を考えることにより，最大ビット荷重（available WOB）を求めることも可能である。垂直井にお

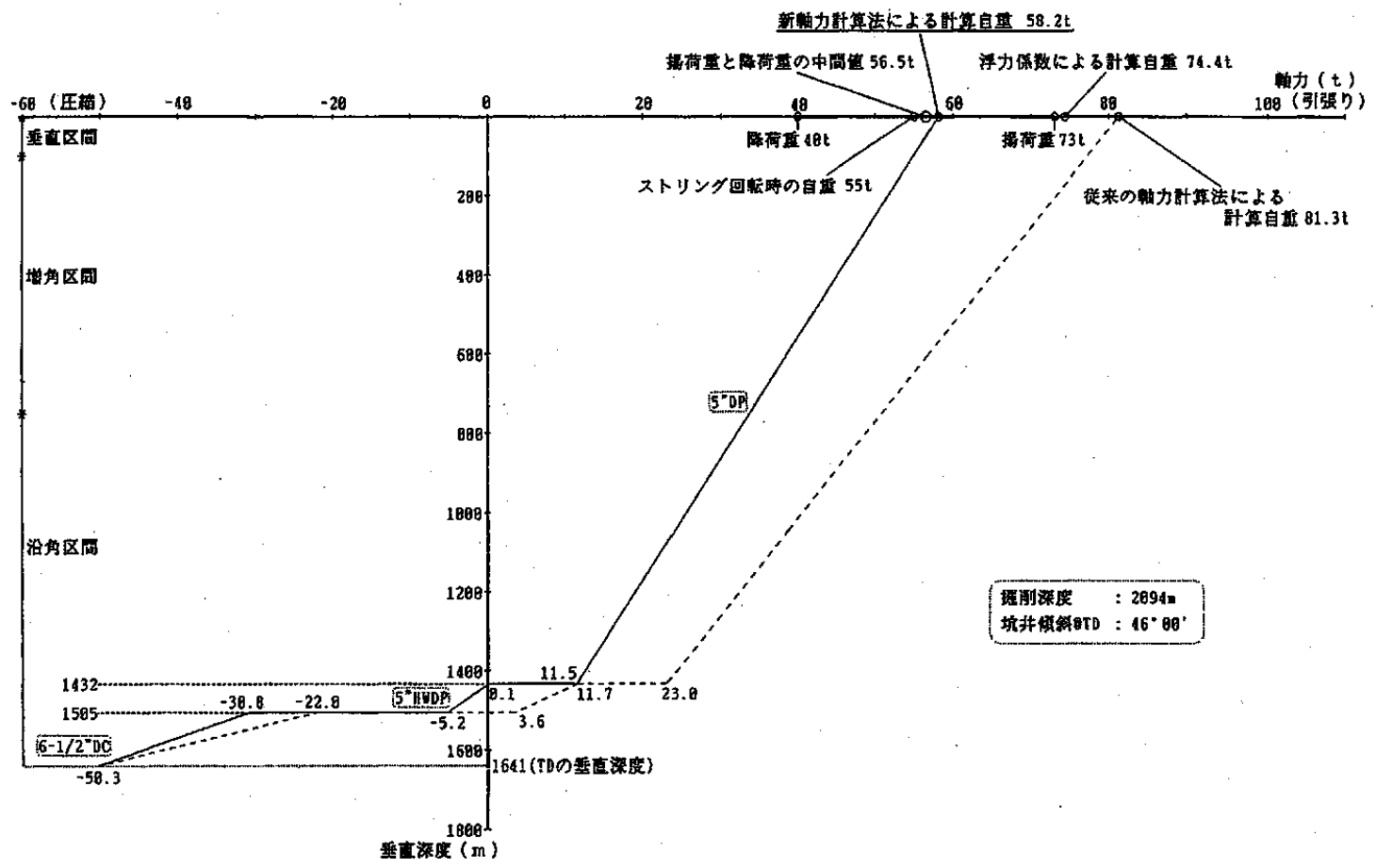

図 8 傾斜井におけるドリルストリングの軸力例（坑井 A 8-1/2" 坑）

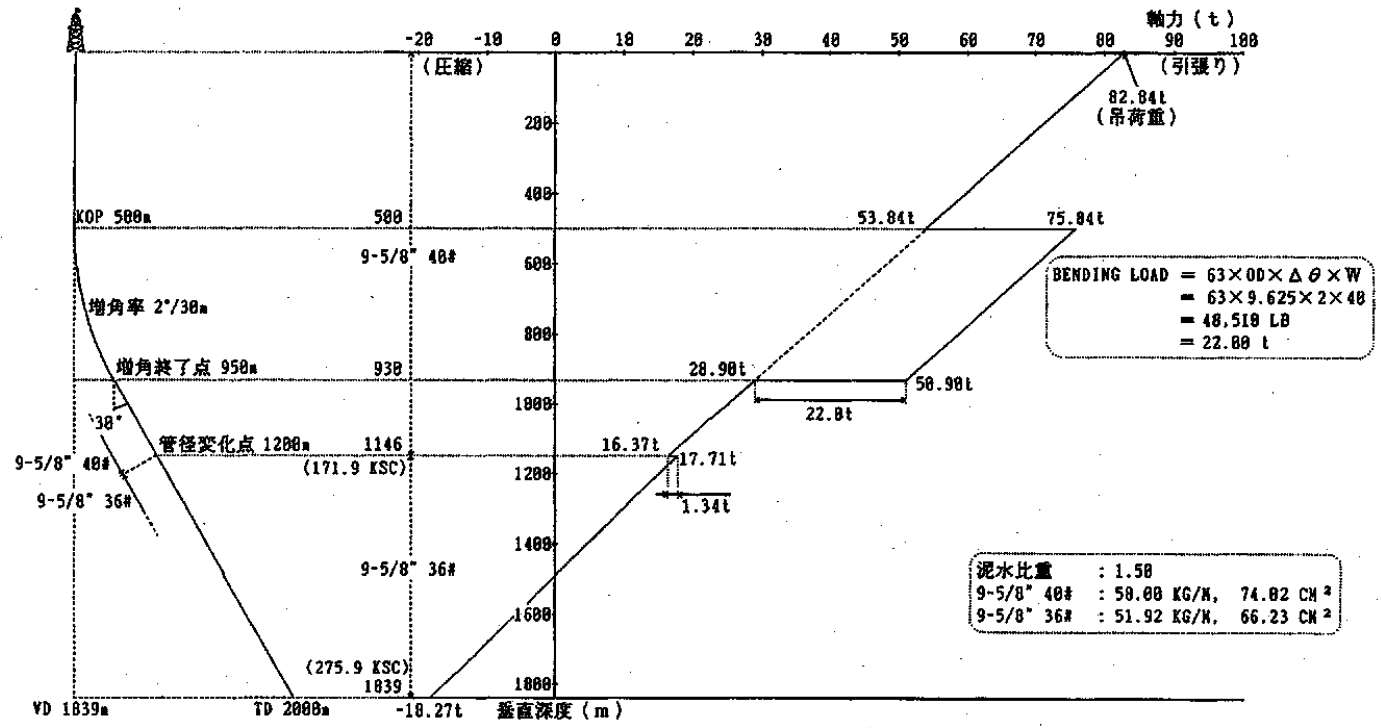

図 9 頃斜井におけるケーシングの軸力例（圧潰耐力の 2 軸補正に使用） 
けるドラグの無い状態でのドリルストリングの軸力の計 算例が，図10である。ビットに荷重をかけると「オフボ トム時の軸力」線が左方にシフトする。玨縮のバックリ ングフォースがドリルカラー (DC) のみにかかるよう にビット荷重をかけるものとすれば（安全率は考えてい ない), DC 上端の軸力が DCのスタビリティーフォー
ス線と交わった時に最大ビット荷重がかかることになる。 この時へビーウェイトドリルパイプ（HWDP）の下端 あHWDPのスタビリティーフォース線と交わる。この 例では, 最大ビット荷重は23.13tである。これは, DC の単位長さ当たりの重量, 長さ, および浮力係数から計 算した DC の泥水中重量と等しい。

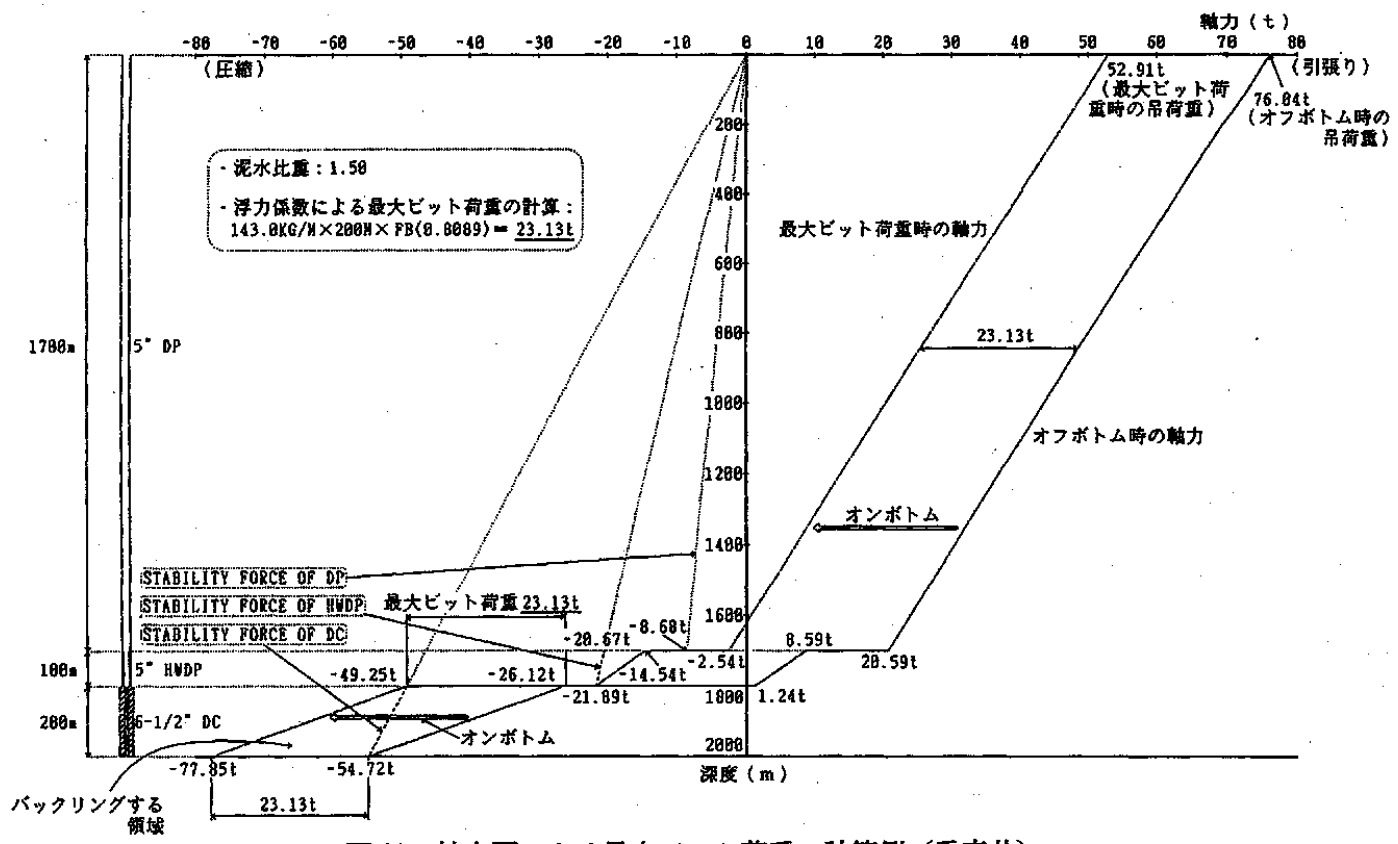

図 10 軸力図による最大ビット荷重の計算例（垂直井）

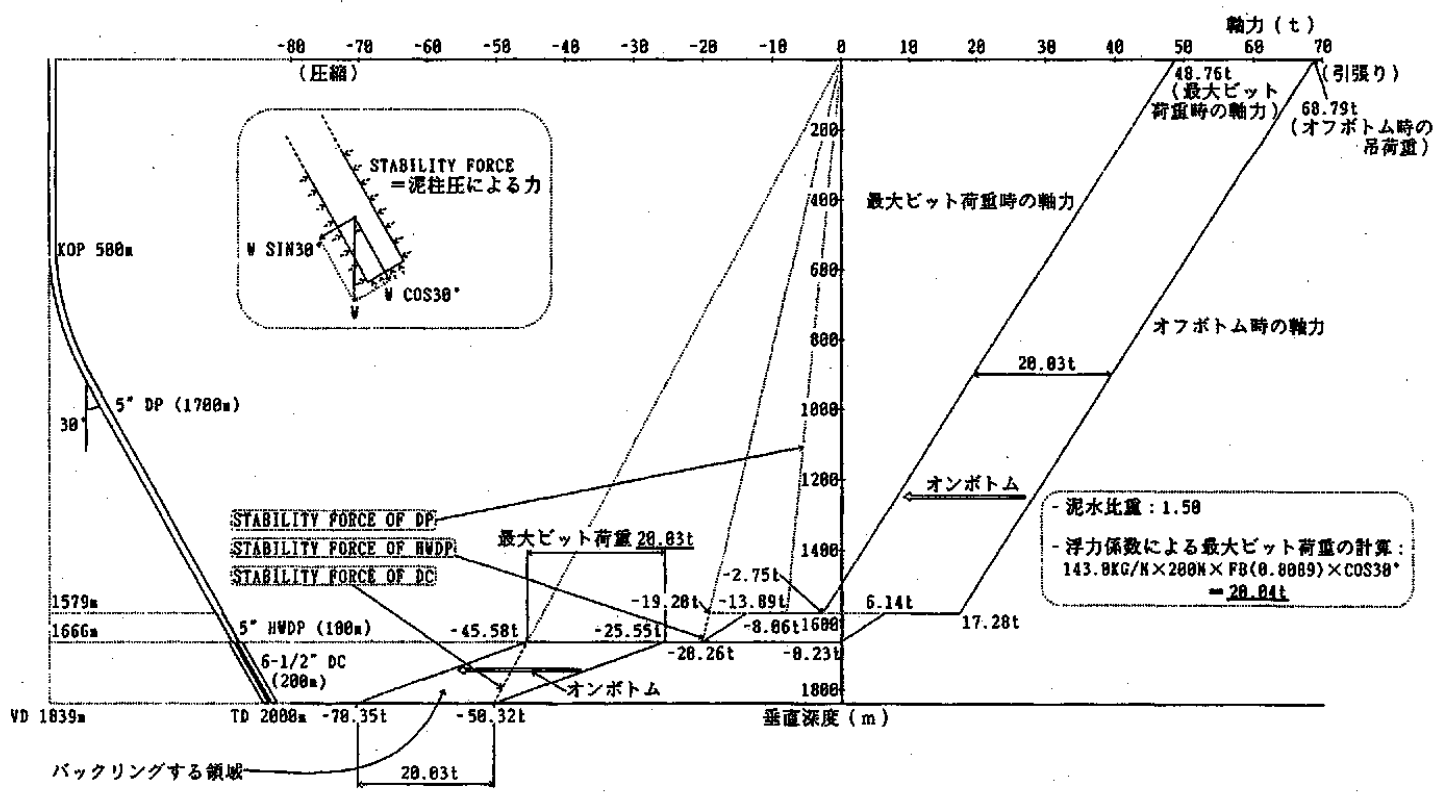

図 11 軸力図による最大ビット荷重の計算例（傾斜井） 
傾斜井の場合の計算例が，図11である。維軸は垂直深 度になる。垂直井の場合と同様に， DC 上端の軸力が $\mathrm{D}$ Cのスタビリティーフォース線と交わった時に最大ビッ 卜荷重がかかることになる。その時のビット荷重は $20.03 \mathrm{t}$ である。これは, DC の単位長さ当たりの重量, 長さ, および浮力係数から計算した DC の泥水中重量 に $\cos \theta$ ( $\theta$ : 傾斜角) を掛けたあのに等しい。ここで 注意すべきは，HWDPに圧縮のバックリングフォース をかけないならば，㑯斜井の場合，DC の泥水中重量が 最大ビット荷重とならないことである

単に最大ビット荷重を知るだけであれば, 軸力図を描 かずとも浮力係数等によりそれを求めることはできる。

\section{2 .5 その他}

坑井内のストリングの自重の理論值があらかじめ求め られれば, 実作業上の様々な許容値・限界値等を知るこ とができ，適正なストリング計画が立てられる。

\section{3 ドラグを考慮する場合の軸力計策の適用}

5.2 の計算結果にドラグ分を付加するのだが, 「增・減 角区間」のドラグについては微小区間での綝り返し計算 が必要となるので，現実にはコンピュータプログラムを 利用することになる。もしそのプログラムがこちらの要 求する機能をすべて有しているとすれば，以下のことが 可能になる。

\subsection{1 ケーシングの引張り設計}

石油資源開発珄におけるケーシングの引張り設計では, ケーシング降下中に各パイブがエレベータに吊られた時 の状況を想定し，それぞれのパイプの下に吊られている 全パイプの泥水中重量に安全係数または安全差荷重を加 えたすのを設計荷重としたマージナルロード法を採用し ている。

しかし, 理想的なケーシングの引張り設計は, ケーシ ング降下開始からセメンチング終了または抑留対策・抜 管終了までの間に，それぞれのパイプ（全パイプ）が遭 遇するであろう最大引張り荷重を考虑したあのでなけれ ばならない。例えば降下終了後坑井深部に位置するパイ プは，その下に吊られているパイプの泥水中重量こそ小 さいすのの，坑井内に大きなドックレグがあれば，そこ を通過するときの曲げ荷重 (bending load) は大きな あのとなり, また大きなドラグあ儌くので, 引張り荷重 はかなり大きなものとなり得る。

降下されるすべてのパイプに対して, 坑内状況や作業 状况に応じた軸力変化をドラグを含めてシミュレーショ ンするプログラムがあれば, ケーシングの完全な引張り 設計が可能となる。

\subsection{2 トルク・ドラグの予測}

ドリルストリングやケーシングのトルク・ドラグを予
測することが可能となる。いわゆる「トルク・ドラグ予 測ブログラム」の利用である。これにより，適正なスト リング計画が可能となる。

\subsection{3 バックオフ荷重の設定}

ストリングの軸力るよびドラグを正確に知ることがで きれば，地表の吊荷重から，バックオフポイントにおけ る軸力を正しく推测することができる。これにより, バッ クオフの際にバックオフポイントに所期の軸力を与える ことができる。

\subsection{4 水平纣井の掘削計画}

ストリングの軸力，ドラグおよびトルクを正確に知る ことができれば, 水平坑井におけるドリルストリング, ケーシング, チュービング等の設計をより厳密に行うこ とができる。また適正な坑跡設計も可能となろう。

\subsection{5 その他}

その他，ストリングの軸力をドラグを含めて正しく知 ることは, 坑内状況の推測, 㧕留の防止や適正なストリ ング設計等に役立つ。

\section{6. まとめ}

頃斜井におけるストリングの軸力について考察した。 そして、ドラグを考慮しない場合の簡便な軸力計算法が 新たに導かれた。また, 項斜井におけるストリングのド ラグについて, その基本的な計算方法を考察した

垂直井であれ，㑯斜井であれ，ドラグを考慮しない場 合のストリングの軸力は, 単位長さ当たりのパイプ空中 重量, 管径変化点の垂直深度, 底面とショルダー面の面 積, おょびそれらに駔く泥柱圧によって, 任意の深度に 対して容易に計算することができる。そして得られた軸 力は, ケーシング圧潰耐力の 2 軸補正，3 軸応力法によ るケーシング設計他，様々なことに応用できる。

ドラグを考虑する場合には，微小区間毎の垂直抗力・ ドラグを考えるが，それらの積算にコンピュータプログ ラムが必要となる。そのプログラムを利用できれば，ス トリングの軸力計算はさらに楅広く応用される。

様々な坑内状況や作業条件に対応可能な軸力計算プロ グラムが開発されることを期待する。

\section{記 号}
A : 棈円の長径
$A i \quad:$ パイプ内周円の面積
Ao : パイプ外周円の面積
$B$ : 椅円の短径
$F B$ : 浮力係数
$\triangle F b$ : 微小区間に勫く浮力
Fn : 微小区間に働く垂直抗力 
$F n h$ : 微小区間に働く垂直抗力の水平方向成分

$h \quad$ : 棈円と等面積の長方形の高さ

ID : パイプの内径

$L \quad$ : パイプの長さ

$\Delta L \quad:$ 微小区間の長さ

$L v \quad:$ 垂直区間の長さ

$L h \quad$ : 沿角区間の長さ

$N$ : 全角度変化を考慮したときの垂直抗力

$O D \quad:$ パイプの外径

$P \quad$ : 泥柱圧

$\mathrm{Pi} \quad$ : パイプの内圧

Po : パイプの外圧

SF : スタビリティーフォース

$T$ : 軸力 (引張りが正)

$\Delta T$ ：微小区間の軸力変化

$T^{\prime} \quad$ : バックリングフォース $\left(=T-S F^{\prime}\right)$

$\Delta T^{\prime}$ : 微小区間のバックリングフォース変化

$T h^{\prime} \quad$ : バックリングフォースの水平方向成分

$W$ : 単位長さ当たりのパイプ空中重量

$W^{\prime} \quad$ : 単位長さ当たりのパイプ泥水中重量 $(=W \times$ 浮力係数 $)$

$W 1,2,3$ : 区間のパイプの空中重量

$\alpha \quad:$ その他のドラグ

$\theta$ : 沿角区間の傾斜角

$\bar{\theta} \quad$ : 增・減角微小区間の平均傾斜角

$\theta d \quad:$ ある深度における傾斜角

$\Delta \theta$ : 傾斜角変化率 (增角 : + , 減角 : - )

$\mu \quad:$ 坑壁の摩擦係数（通常 $0.25 \sim 0.40 ）$

$\rho:$ : 泥水密度

$\phi \quad:$ 方位角

$\Delta \phi \quad:$ 方位角变化率

\section{略号}

API : American Petroleum Institute

$\mathrm{DC}$ : ドリルカラー

$\mathrm{DP}$ : ドリルパイプ
HWDP : ヘビーウエイトドリルパイプ

KOP : 増角開始点

TD : 掘削深度

VD : 垂直深度

WOB : ビット荷重

\section{参 考 献}

American Petroleum Institute, 1989: API Bulletin $5 \mathrm{C} 3$-Bulletin on Formulas and Calculations for Casing, Tubing, Drill Pipe and Line Pipe Properties- fifth edition. 5-16, API.

GoINS, W.C., 1980a: Better understanding prevents tubular buckling problems PART 1. World Oil, January 1980, 101-106.

GoINS, W.C., 1980b: Better understanding prevents tubular buckling problems PART 2. World Oil, February 1980, 35-40.

GREENIP, J.F. Jr., 1989: How To Design Casing Strings For Horizontal Wells. Petroleum Engineer International, December 1989, 34-38.

HAMMERLINDL, D.J., 1978: Basic Fluid and Pressure Forces on Oilwell Tubulars. JPT., January $1980,153-159$.

JOHANCSIK, C.A., FRIESEN, D.B. and DAWSON, R., 1984: Torque and Drag in Directional WellsPrediction and Measurement. JPT., June 1984, 987-992.

LUBINSKI, A., Althouse, W.S., and LOGAN, J.L., 1962: Helical Buckling of Tubing Sealed in Packers. JPT., June 1962, 655-670.

LUBINSKI, A., 1988: Developments in Petroleum Engineering volume two. 157-178, Gulf Publishing Company.

SHEPPARD, M.C., WICK, C., and BURGESS, T., 1986: Designing Well Paths To Reduce Drag and Torque. SPE 15463. 